\title{
ПРАВОВЕ РЕГУЛЮВАННЯ ЗАПОБІГАННЯ КОРУПЦЙНИМ РИЗИКАМ ПІД ЧАС НАДАННЯ ЕЛЕКТРОННИХ ПОСЛУГ У СФЕРІ МІГРАЦІЇ ТА ГРОМАДЯНСТВА У СФЕРІ МІГРАЦІї ТА ГРОМАДЯНСТВА
}

\section{ЮРЧЕНКО Віктор Валерійович - секретар судового засідання Господарського суду Дніпропетровської області \\ DOI 10.32782/LAW.UA.2021.4.21}

Наукова стаття присвячена правовому регулюванню запобігання корупий під час надання електронних послуг у сфері міграциї та громадянства. В Украӥні на съогоднішній час правова основа запобігання корупиій під час надання електронних послуг у сбері міграмї та громадянства потребує удосконалення. Адже в Законі Україні «Про адміністративні послуги» характеристика механізму процедури надання електронних послуг у сбері міграиї та громадянства шодо запобігання корупиї містить тільки формальні аспекти та має відсильний характер щодо інших нормативноправових актів, що, у свою чергу, призводить до власного і доволі протилежного тлумачення норм суб'єктами публічної адміністращй.

Щодо напрямів удосконалення правовоі основи запобігання корупиіӥ під час надання електронних послуг у сбері мігращиї та громадянства $\epsilon$ : розроблення та прийняття Закону України «Про адміністративні процедури»; розмір оплати за види електронних послуг мають визначатись лише у законах, а не у підзаконних нормативно-правових актах; розробити та прийняти Закон України «Про адміністративний збір», у якому має бути уніфіковано назву плати за адміністративні послуги; необхідно визначити єдині розміри адміністративних зборів для всіх видів електронних послуг.

Обгрунтовано доиільність негайного ухвалення законопроєкту № 4267-1 від 23.03.2016 як Закону України "Про внесення змін та доповнень до Закону України «Про адміністра- тивні послуги», який змічнить нормативну базу надання електронних послуг у сбері міграиї та громадянства органами публічної адміністраиії бізичним або юридичним особам, котре здійснюється в електронному вигляді, $i$ сприятиме запобіганню корупиї під час надання електронних послуг у сбері міграий та громадянства взагалі.

Встановлено, що існування корупиійних налагоджених механізмів у вітчизняній системі адміністративного управління, щзо склалася традииійно, робить проблему налагодження електронного надання електронних послуг у сфері міграиї та громадянства такою, що виходить за межі суто технічно-інбормаиійних.

Ключові слова: послуга, електронна послуга, запобігання корупиї, напрямки, нормативно-правовий акт, правове регулювання.

\section{Вступ}

Европейський вибір України означає активнішу реалізацію електронних послуг, без яких не можуть розвиватися освітянська, наукова, підприємницька, господарська та інші види суспільної діяльності, міжнародні та дипломатичні зв'язки тощо, зокрема процедури надання електронних послуг у сфері міграції та громадянства, у діяльності органів публічної адміністрації.

Згідно з Конституцією України людина, іiї права та свободи в Україні є головною соціальною цінністю, а головним завданням органів публічної адміністрації виступає надання якісних послуг фізичним та юри- 
дичним особам. Це випливає із сутності нової ролі держави у відносинах 3 людиною, закріпленою в Конституції України. Так, ст. 3 Основного Закону проголошує: «Утвердження і забезпечення прав і свобод людини є головним обов'язком держави». Споживачі послуг процедури надання електронних послуг у сфері міграції та громадянства у відносинах із органами публічної влади $є$ не прохачами, а відповідними споживачами зазначених послуг. Також органи держави в особі публічно-владних органів мають орієнтуватися на потреби громадян, як у цивільному та господарському секторі надавачі будь-яких послуг орієнтуються на потреби споживача [1].

У зв'язку із цим у науковій літератуpi починають звертати увагу на таку нову функцію органів публічної адміністрації, як процедури надання електронних послуг у сфері міграції та громадянства, оскільки ця функція становить найважливішу складову управлінської діяльності, походить від загального змісту державного управління, становить змістову характеристику діяльності тощо.

\section{Огляд літератури}

Буханевич О.М. зазначає, що наявність прогалин у правовому регулюванні платних та безоплатних електронних послуг у більшості пояснює ті негативні явища, які заважають розвитку прозорої системи надання електронних послуг у сфері міграції та громадянства [2, с. 181]. Їх усуненню, хоча 6 частково, може сприяти прийняття системного нормативно-правового акта 3 питань плати за надання електронних послуг у сфері міграції та громадянства (наприклад, Закон України «Про плату за надання електронних послуг у сфері міграції та громадянства» або Закон України «Про адміністративний збір») [2, с. 181]. Саме такий законодавчий акт може бути, на наш погляд, правовою основою розвитку прямих і зворотних зв'язків між суб'єктами надання електронних послуг у сфері міграції та громадянства та суб'єктами звернення, а також був би суттєвим підгрунтям для забезпечення стабільності та прозорості розвитку держави та органів місцевого самоврядування [2, с. 181].
Ємельяненко О. вважає: «Електронні послуги - це надання в електронній формі урядової інформації: програм і напрямів діяльності уряду, формування стратегій задля розв'язання найважливіших суспільних проблем. Електронні послуги характеризуються новими формами громадянської участі та співробітництва між владою й громадянами» [19].

Аегеза G.О. під електронними послугами розуміє різні види матеріальних і нематеріальних послуг, що надаються в електронній формі 3 використанням інформаційно-комунікаційних технологій (далі - IКТ), включаючи Інтернет» [20, с. 17].

На думку вченого Куспляка I.C., доречніше використовувати термін «електронні послуги», тобто в цифровому вигляді, пов'язані з використанням документообігу [21].

Проте категорія електронних послуг не розкрита в законодавчих актах, що, у свою чергу, свідчить про актуальність теми.

\section{Мета та задачі дослідження}

Метою статті розкриття правового регулювання запобігання корупційних ризикам під час надання електронних послуг у сфері міграції та громадянства.

Правова основа запобігання корупційним ризикам під час надання електронних послуг у сфері міграції та громадянства. В Указі Президента України від 22.07.1998 № 810 «Про заходи щодо впровадження Концепції адміністративної реформи в Україні» йдеться про запровадження надання електронних послуг у сфері міграції та громадянства [5]. У розпорядженні Кабінету Міністрів України від 15.02.2006 № 90-р «Про затвердження Концепції розвитку системи надання електронних послуг у сфері міграції та громадянства органами виконавчої влади», у якому визначено сфери надання електронних послуг у сфері міграції та громадянства тощо [6].

Так, ст. 3 Закону України «Про звернення громадян» у зміст звернення включає не тільки заяви, пропозиції, зауваження та клопотання, але і скарги громадян, викладені в письмовій або усній формі [17]. Пода- 


\section{Цивільне, підприємницьке, господарське та трудове право}

ча скарг до відповідних суб'єктів правовідносин $з$ надання електронних послуг у сфеpi міграції та громадянства є невід'ємним правом громадян та інших осіб. Це право є конституційним, адже Основний Закон України в ст. 40 закріпив його, вказавши, що «всі мають право направляти індивідуальні чи колективні письмові звернення або особисто звертатися до органів державної влади, органів місцевого самоврядування та посадових і службових осіб цих органів, що зобов'язані розглянути звернення і дати обгрунтовану відповідь у встановлений законом строк» [4].

Незважаючи на наявність у тексті Закону України «Про адміністративні послуги» від 06 вересня 2012 року № 5203-VI [9] окремих слушних положень, які здатні в цілому позитивно вплинути на правовідносини у вказаній сфері суспільного життя (наприклад, слушними є новели, якими встановлено пріоритет законодавчого регулювання строків надання електронних послуг у сфері міграції та громадянства (ст. 10) та оплати електронних послуг (ст. 11); схвально може бути оцінена законодавча пропозиція щодо заборони надання супутніх послуг адміністративними органами та суб'єктами господарювання, ними утвореними (ч. 4 ст. 15), залишаються деякі положення, які потребують узгодження, а саме:

- дефініція електронних послуг, наведена в Законі, виглядає досить повною та змістовною: «адміністративна послуга - peзультат здійснення владних повноважень суб'єктом надання електронних послуг у сфері міграції та громадянства за заявою фізичної або юридичної особи, спрямований на набуття, зміну чи припинення прав та/ або обов'язків такої особи відповідно до закону». Але при цьому викликає здивування факт, що це визначення наводиться чомусь в преамбулі, тоді як, як нам відомо, законотворча практика вимагає викладення у преамбулі основного змісту закону, аж ніяк не визначення понять[9];

- доктрина електронних послуг радикально відрізняється від характеру управлінських відносин, закріплених у вітчизняному законодавстві, і грунтується на постулатах, що розглядають адміністративне право не як «управлінське», а як «публічно-сервісне», начебто спрямоване на обслуговування потреб та інтересів приватних осіб у їхніх стосунках з адміністративними органами. Така оцінка правової природи відносин між владою та громадянами є дискусійною у науці адміністративного права, тому виникають сумніви щодо готовності до її впровадження у вітчизняне законодавство[9];

- у ст. 11 Закону України «Про адміністративні послуги» [9] розкрито засади оплати надання електронних послуг у сфері міграції та громадянства;

— редакція ст. 12 та 13 Закону України, за якою парламенту пропонується унормувати законом питання структури місцевих державних адміністрацій та виконавчих органів місцевих рад. Ідеться про створення за законом центрів надання електронних послуг у сфері міграції та громадянства як структурних підрозділів (або як робочих органів) місцевих державних адміністрацій та виконавчих органів міських рад і запровадження посад адміністраторів [9].

Необхідно відмітити, що законодавець, формулюючи загальні засади визначення платності електронних послуг, порядку оплати платних електронних послуг та обмежень щодо справляння та використання коштів за послуги суб'єктами надання електронних послуг у сфері міграції та громадянства, самоусунувся від закріплення на законодавчому рівні сутності категорії «плата за надання електронних послуг у сфері міграції та громадянства (адміністративний збір)», а також встановлення ознак, властивих цьому платежу. Зауважимо, що з'ясування правової природи плати за надання електронних послуг у сфері міграції та громадянства має не тільки теоретичне, але і практичне значення. Від того, яку правову природу має цей платіж, будуть залежати, зокрема, рівень нормативного регулювання, наслідки несплати плати за надання адміністративної послуги, повноваження суб'єктів надання електронних послуг у сфері міграції та громадянства щодо суб'єктів звернення тощо [7, с. 45].

На сьогоднішній час існуе ряд підзаконних нормативно-правових актів, які ре- 
гулюють процедуру надання електронних послуг у сфері міграції та громадянства, зокрема, постанови Кабінету Міністрів України «Про затвердження Порядку ведення Єдиного державного порталу електронних послуг» [13], «Про затвердження Порядку ведення Реєстру електронних послуг» [14], «Про затвердження вимог до підготовки технологічної картки адміністративної послуги» [11], «Про затвердження Примірного положення про центр надання електронних послуг у сфері міграції та громадянства» [15], «Про затвердження Примірного регламенту центру надання електронних послуг у сфері міграції та громадянства» [16], «Деякі питання ведення обліку доходів, які надходять як плата за надання електронних послуг у сфері міграції та громадянства» [3]. Також необхідно зазначити на схвалені КМУ Концепції Державної цільової програми створення та функціонування інформаційної системи надання електронних послуг у сфері міграції та громадянства на період до 2017 року [18] та затверджено План заходів щодо створення Сдиного державного порталу електронних послуг [12].

Нині на розгляді й опрацюванні Комітету з питань державного будівництва, регіональної політики та місцевого самоврядування перебуває досить вдалий, на наш погляд, законопроєкт України № 4267-1 від 23.03.2016 «Про внесення змін та доповнень до Закону України «Про адміністративні послуги» [10] щодо покращення умов надання електронних послуг у сфері міграції та громадянства», підготований групою народних депутатів (Є. В. Соболєв, А. А. Романова, С. П. Фірсов, В. В. Пацкан, А. О. Емець, П. П. Костенко, М. В. Кобцев, Я. В. Маркевич, Д. Е. Добродомов, I. I. Мельничук).

Законопроєкт передбачає внесення змін до Закону України «Про адміністративні послуги» [10] щодо доповнення переліку суб'єктів надання електронних послуг у сфері міграції та громадянства акредитованими суб'єктами, вимоги та порядок акредитації яких встановлюватиметься Кабінетом Міністрів України. Коло адміністративних центрів доповнюється можли- вістю створення їх обласними державними адміністраціями на обласному рівні. Закріплюється можливість отримання адміністративної послуги незалежно від місця знаходження суб'єкта надання адміністративної послуги, а також суб'єкта звернення, місця провадження його діяльності та місця знаходження відповідного об'єкта, крім випадків, установлених законом (екстериторіальність), можливість подання електронних заяв на отримання електронних послуг напряму через веб-сайти суб'єктів їх надання. Суб'єктам надання електронних послуг у сфері міграції та громадянства забезпечується безоплатний віддалений доступ через відкриті для них та адміністраторів центрів надання електронних послуг у сфері міграції та громадянства АРІ-адреси до інформаційних систем та електронних баз даних (реєстрів), що містять інформацію, необхідну для надання електронних послуг у сфері міграції та громадянства. Суб'єкти надання електронних послуг у сфері міграції та громадянства зобов'язуються надавати в електронній формі всі адміністративні послуги, крім тих, результат надання яких відповідно до закону потребує використання спеціальних бланків та/або інших особливих матеріальних форм свого виразу (паспорти, пластикові картки, автомобільні номери тощо). Встановлюється, що 40 \% адміністративного збору спрямовується до відповідного бюджету, а $60 \%$ - безпосередньо акредитованому суб'єкту.

Законопроєкт України № 4267-1 від 23.03.2016 «Про внесення змін та доповнень до Закону України «Про адміністративні послуги» [10] пропонує доповнення статті 1 новим визначенням поняття «електронна заява», під яким розуміється заява про отримання адміністративної послуги, яка формується і подається через веб-сайт суб'єкта надання електронних послуг у сфері міграції та громадянства або через Единий державний портал електронних послуг, у тому числі через інтегровані з ним інформаційні системи державних органів та органів місцевого самоврядування.

Дуже слушною є пропозиція щодо внесення змін до статті 9 Закону України «Про адміністративні послуги» [9], а саме: 


\section{Цивільне, підприсмницьке, господарське та трудове право}

у першому реченні абзацу другого частини першої після слів «в електронній формі надаються» додати слова «через веб-сайти суб'єктів надання електронних послуг у сфері міграції та громадянства або»; частину другу викласти в такій редакції: «2. Суб'єкт звернення має право на отримання адміністративної послуги незалежно від місця знаходження суб'єкта надання адміністративної послуги, а також суб'єкта звернення (включаючи реєстрацію місця проживання фізичної особи), місця провадження його діяльності та місця знаходження відповідного об'єкта (екстериторіальність), крім випадків, установлених законом»; частину третю виключити; в абзаці другому частини четвертої після слів «в електронній формі» додати слова «(електронна заява) - через веб-сайт суб'єкта надання електронних послуг у сфері міграції та громадянства або»; у частині восьмій після слів «шляхом прямого доступу» додати слова «через відкриті API-адреси»; у частині дев'ятій: у пункті 4 після слів «у тому числі через» додати слова «відкриті АРІ-адреси відповідних інформаційних систем та електронних баз даних (реєстрів) та»; пункт 5 викласти в такій редакції: «5) забезпечити надання в електронній формі всіх електронних послуг, крім тих, результат надання яких відповідно до закону потребує використання спеціальних бланків та/або інших особливих матеріальних форм свого виразу (паспорти, пластикові картки, автомобільні номери тощо)».

Також вважаємо слушними формулювання пропонованих змін до статті 12 Закону України «Про адміністративні послуги» [9] щодо суб'єктів надання адміністративних послуг, а саме: «У разі не утворення обласними чи районними державними адміністраціями центрів надання електронних послуг у сфері міграції та громадянства у населених пунктах, які $\varepsilon$ адміністративними центрами областей, районів і Автономної Республіки Крим, а також у містах Києві та Севастополі, центри надання електронних послуг у сфері міграції та громадянства, що утворені за рішенням відповідних селищних або міських рад, можуть забезпечувати надання електронних послуг у сфері міграції та громадянства, у тому числі відпо- відними обласними, районними та міськими державними адміністраціями, на основі узгоджених рішень.

У разі утворення центрів надання електронних послуг у сфері міграції та громадянства районними та/або обласними державними адміністраціями такі центри можуть забезпечувати надання електронних послуг у сфері міграції та громадянства обласних, районних державних адміністрацій та органів місцевого самоврядування на основі їх узгоджених рішень».

Аналізуючи текст чинного Закону «Про адміністративні послуги» [9], у ст. 5 його знаходимо вимогу, згідно з якою встановлення підстав для одержання адміністративної послуги, коло суб'єктів надання адміністративної послуги та їх повноваження, перелік та вимоги до обов'язкових для отримання адміністративної послуги документів, платність або безоплатність надання адміністративної послуги, терміни їх надання та підстави для відмови у наданні адміністративної послуги визначаються тільки законами України. Однак коментатори Закону зазначають, що такі положення, як перелік та вимоги до документів, необхідних для отримання адміністративної послуги; умови платності або безоплатності їі надання; підстави для відмови у іiі наданні, на жаль, не знайшли чіткого затвердження в жодному законодавчому акті. Зазначені положення, на наш погляд, також потребують необхідної нормативної регуляції за допомогою внесення змін до Закону України «Про адміністративні послуги».

\section{1. Охарактеризовано нормативно-пра-} вові акти корупційних ризиків під час надання електронних послуг в сфері міграції та громадянства. Зокрема, в Законі Україні «Про адміністративні послуги» характеристика механізму процедури надання електронних послуг у сфері міграції та громадянства щодо запобігання корупції містить тільки формальні аспекти та має відсильний характер щодо інших нормативно-правових актів, що, у свою чергу, призводить до власного і доволі протилежного тлумачення норм суб’ єктами публічної адміністрації. 
2. Виокремлено напрямки удосконалення правового регулювання корупційних ризиків під час надання електронних послуг у сфері міграції та громадянства. Так, до напрямів удосконалення правової основи запобігання корупції під час надання електронних послуг у сфері міграції та громадянства є: розроблення та прийняття Закону України «Про адміністративні процедури»; розмір оплати за види електронних послуг мають визначатись тільки у законах, а не у підзаконних нормативно-правових актах; розробити та прийняти Закон України «Про адміністративний збір», у якому має бути уніфіковано назву плати за адміністративні послуги; необхідно визначити єдині розміри адміністративних зборів для всіх видів електронних послуг.

Позитивно оцінюючи запропоновані законопроєктом нововведення, підтримуємо пропозицію про негайне ухвалення законопроєкту № 4267-1 від 23.03.2016 як Закону України «Про внесення змін та доповнень до Закону України «Про адміністративні послуги», що, на нашу думку, зміцнить нормативну базу надання електронних послуг у сфері міграції та громадянства органами публічної адміністрації фізичним або юридичним особам, котре здійснюється в електронному вигляді, і сприятиме запобіганню корупції під час надання електронних послуг у сфері міграції та громадянства взагалі.

\section{Лiтература}

1. Тимощук В.П. Адміністративна процедура та адміністративні послуги. Зарубіжний досвід і пропозиції для України. К.: Факт, 2003. С. 496.

2. Буханевич О. М. Теоретико-правові та праксеологічні засади надання електронних послуг у сфері міграції та громадянства в Україні : дис. ... докт. юрид. наук : спец. 12.00.07 «Адміністративне право і процес; фінансове право; інформаційне право»; Iн-т законодавства Верховної Ради України. К., 2016. 455 с.

3. Деякі питання ведення обліку доходів, які надходять як плата за надання електронних послуг у сфері міграції та громадянства: постанова Кабінету Міністрів України від 7 серпня 2013 року № 600. URL: http://zakon4.rada.gov.ua/laws/show/6002013-n.
4. Іващенко О.Ю. Оскарження електронних послуг у Великій Британії та Україні (порівняльно-правовий аналіз) : дис. ... канд. юрид. наук : 12.00.07. К., 2012. 234 c.

5. Концепція адміністративної реформи в Україні. К. : Державна комісія з проведення в Україні адміністративної реформи, 1998. 62 с

6. Концепція розвитку системи надання електронних послуг у сфері міграції та громадянства органами виконавчої влади : Розпорядження Кабінету Міністрів України від 15.02.2006 № 90-р. // Офіційний вісник України. 2006. № 7. С. 168-170.

7. Оніщик Ю.В., Буханевич О.М. Правове регулювання плати за надання електронних послуг у сфері міграції та громадянства: проблеми теорії та практики. Науков записки Інституту законодавства Верховной Ради Украӥни. 2015. - № 3. - С. 43-48.

8. Острах М. Б. Поняття електронних послуг: теоретичний аспект. Держава $і$ nраво: збірник наукових працъ. К., 2009. С. 155159.

9. Про адміністративні послуги: Закон України від 6 вересня 2012 року № 5203-VI. Відомості Верховної Ради України. 2013. № 32. Cт. 409.

10. Про внесення змін та доповнень до Закону України «Про адміністративні послуги» щодо покращення умов надання електронних послуг у сфері міграції та громадянства» : законопроект ВРУ України№ 4267-1 від 23.03.2016. URL: ht t p://w 1.c1.rada.gov.ua/pls/zweb2/ webproc4_1?pf3511=58495

11. Про затвердження вимог до підготовки технологічної картки адміністративної послуги: Постанова Кабінету Міністрів України від 30 січня 2013 року № 44. URL:: http: //zakon2 .rada. gov .ua/l aws/show/44-2013-п/рагап7 \#n7.

12. Про затвердження плану заходів щодо створення Єдиного державного порталу електронних послуг: Розпорядження Кабінету Міністрів України від 11 вересня 2013 року № 718-p URL: http://zakon4.rada. gov.Ua/laws/show/718-2013-p.

13. Про затвердження Порядку ведення Єдиного державного порталу електронних послуг: Постанова Кабінету Міністрів 


\section{Цивільне, підприсмницьке, господарське та трудове право}

України від 3 січня 2013 року № 13 [Електронний ресурс]. - Режим доступу: http: // zakon2 .rada. gov.ua/laws/show/13-2013 -п/ рагап9\#п9.

14. Про затвердження Порядку ведення Реєстру електронних послуг: Постанова Кабінету Міністрів України від 30 січня 2013 року № 57. URL: http://zakon4.rada. gov.ua/laws/show/57- 2013-п.

15. Про затвердження Примірного положення про центр надання електронних послуг у сфері міграції та громадянства: Постанова Кабінету Міністрів України від 20 лютого 2013 року № 118. URL: http: // zakon2 .rada. gov .ua/l aws/show/118-2013-п/ рагап8\#п8.

16. Про затвердження Примірного регламенту центру надання електронних послуг у сфері міграції та громадянства: Постанова Кабінету Міністрів України від 1 серпня року № 588. URL: http: //zakon4. rada. gov .ua/laws/show/588-2013-п.

17. Про звернення громадян: Закон України від 2 жовтня 1996 р. № 393/96-ВР. Відомості Верховної Ради України. 1966. № 47. Ciт. 256.

18. Про схвалення Концепції Державної цільової програми створення та функціонування інформаційної системи надання електронних послуг у сфері міграції та громадянства на період до 2017 року: Розпорядження Кабінету Міністрів України від 24 липня року № 614-p. URL: http://zakon4. rada.gov.ua/laws/show/614-2013-p.

19. Емельяненко О. Традиційний та електронний уряд: концептуальні відмінності. URL: : http://www.viche.info/ journal/811/.

20. Аегеза E.О. Адміністративні послуги, що надаються міліцією громадської безпеки: дис. ... канд. юрид. наук : 12.00.07 Дніпропетровськ, 2011. 263 с.

21. Куспляк I.C. Електронне урядування як інструмент формування прозорої та відкритої політичної влади: дис. ... канд. політ. наук : 23.00.02. Одеса, 2012. 206 с.
The scientific article is devoted to the legal regulation of corruption prevention in the provision of electronic services in the field of migration and citizenship. In Ukraine today, the legal framework for preventing corruption in the provision of electronic services in the field of migration and citizenship needs to be improved. After all, in the Law of Ukraine "On Administrative Services" the description of the mechanism of providing electronic services in the field of migration and citizenship to prevent corruption contains only formal aspects and has a reference character to other regulations, which, in turn, leads to its own and quite opposite interpretation of norms by subjects of public administration.

Regarding the areas of improving the legal basis for preventing corruption in the provision of electronic services in the field of migration and citizenship are: development and adoption of the Law of Ukraine "On Administrative Procedures"; the amount of payment for types of electronic services should be determined exclusively in laws, and not in bylaws; develop and adopt the Law of Ukraine "On Administrative Fees", which should unify the name of the fee for administrative services; it is necessary to determine the uniform size of administrative fees for all types of electronic services.

The expediency of immediate adoption of the draft law № 4267-1 of 23.03.2016 as the Law of Ukraine "On Amendments to the Law of Ukraine" On Administrative Services ", which will strengthen the regulatory framework for the provision of electronic services in the field of migration and citizenship by public administration to individuals or legal entities, which is carried out in electronic form, and will help prevent corruption in the provision of electronic services in the field of migration and citizenship in general.

It is established that the existence of corrupt mechanisms in the domestic system of administrative management, which has developed traditionally, makes the problem of establishing electronic provision of electronic services in the field of migration and citizenship such that goes beyond purely technical and information.

Key words: service, electronic service, prevention of corruption, directions, normative-legal act, legal regulation. 